\title{
PEMERIKSAAN KANDUNGAN BAHAN KIMIA OBAT (BKO) PREDNISON PADA BEBERAPA SEDIAAN JAMU REMATIK
}

\author{
Ade Wirastuti ${ }^{1}$, A. Amaliah Dahlia, Ahmad Najib \\ Fakultas Farmasi, Universitas Muslim Indonesia \\ 1adewirastuti@yahoo.co.id
}

\begin{abstract}
A study of identification and assay of prednisone in rheumatic jamu. The aim of this study to identify the presence of Chemicals Drug (CD) in containing prednisone in rheumatic jamu with TLC-densitometry method. Samples extracted with Mesceration method using etanol $96 \%$ solvent by sonicator. Qualitative analysis using thin layer chromatography (TLC) with a mobile phase of chloroform : ethyl acetate (1:9) indicates that the sample A containing Prednison. Quantitative analysis using a TLC-densitometry at a maximum wave-length $254 \mathrm{~nm}$. The result is one containing prednisone that suspected sample " $\mathrm{A}$ " is $475,421 \mu \mathrm{g} / \mathrm{mL}$ and the percentage is $4,754 \%$.
\end{abstract}

Keywords: Chemicals drug, Jamu, Prednisone, TLC-Densitometry

\section{PENDAHULUAN}

Secara lebih detail, definisi jamu atau obat tradisional adalah bahan atau ramuan bahan yang berupa bahan tumbuhan, bahan hewan, bahan mineral, sediaan sarian (galenik), atau campuran dari bahan tersebut yang secara turun-temurun telah digunakan untuk pengobatan berdasarkan pengalaman. Sesuai dengan peraturan perundangundangan yang berlaku, obat tradisional dilarang menggunakan bahan kimia hasil isolasi atau sintetik berkhasiat obat yang sering disebut dengan bahan kimia obat (BKO) (Yuliarti, 2010).

BKO dalam obat tradisional inilah yang menjadi titik penjualan bagi produsen. Hal ini kemungkinan disebabkan kurangnya pengetahuan produsen akan bahaya mengkonsumsi bahan kimia obat secara tidak terkontrol, baik dosis maupun cara penggunaannya atau bahkan semata-mata demi meningkatkan penjualan karena konsumen menyukai produk obat tradisional yang bereaksi cepat pada tubuh (Yuliarti, 2010).

Obat-obatan yang mengandung steroid bisa mempercepat osteoporosis, misalnya prednison, prednisolon, kortison, termasuk jamu atau obat tradisional yang biasanya juga mengandung steroid, yang diberikan pada penyakit rematik, asma, radang usus atau beberapa penyakit kanker. Makin tinggi dosis dan makin lama pemakaian, resiko osteoporosis menjadi makin besar (Tandra, 2009).

Prednison dosis tinggi atau jangka panjang berisiko mengalami keropos tulang. Keropos tulang mungkin merupakan efek samping pengobatan steroid yang paling serius. Pada orang-orang yang menerima prednison dengan dosis harian sebesar 7,5 $\mathrm{mg}$ atau lebih, resiko patah ruas tulang belakang lima kali lebih tinggi ketimbang orang-orang yang tidak menerima steroid (Cosman, 2011).
Berdasarkan hal tersebut, maka akan dilakukan penelitian identifikasi dan penentuan kadar bahan kimia obat (BKO) prednison pada beberapa sediaan jamu rematik sehingga dapat digunakan sebagai referensi bagi masyarakat tentang keamanan dari beberapa sediaan jamu rematik yang beredar di pasaran.

\section{METODE PENELITIAN \\ A. Ekstraksi sampel secara Maserasi}

Sampel jamu A ditimbang kurang lebih 1 gram di masukkan kedalam gelas kimia, lalu di tambahkan etanol $96 \%$ kurang lebih $20 \mathrm{~mL}$, kemudian di sonikasi selama 20 menit, saring dan tampung ekstrak cair dari sampel jamu (perlakuan triplo). Lakukan perlakuan yang sama untuk masingmasing sampel jamu B, C, D dan E (Wisnuwardhani et al, 2013 yang telah dimodifikasi).

\section{B. Penguapan Ekstrak}

Ekstrak etanol cair sampel jamu rematik A, $\mathrm{B}, \mathrm{C}, \mathrm{D}$ dan $\mathrm{E}$ diuapkan dengan cara dianginanginkan sehingga diperoleh ekstrak etanol kental jamu A, B, C, D dan E.

\section{Identifikasi Kromatografi lapis tipis (KLT)}

Ekstrak etanol jamu A dan senyawa pembanding Prednison ditotolkan pada lempeng KLT dengan ukuran 4 x $7 \mathrm{~cm}$, dimasukkan ke dalam chamber yang berisi eluen Kloroform : Etil asetat (1 : 9). Setelah eluen mencapai batas tanda, angkat dan keringkan. Kemudian kromatogram yang dihasilkan diamati nodanya di bawah sinar ultra violet (UV) pada panjang gelombang $254 \mathrm{~nm}$ dan $366 \mathrm{~nm}$. Dibandingkan noda yang terdapat pada senyawa pembanding dengan ekstrak jamu dan perhatikan ada tidaknya kesamaan pada penampakan noda dan hitung 
nilai Rf-nya. Lakukan perlakuan yang sama untuk sampel jamu B, C, D dan E (Firdaus \& Utami, 2009 yang telah dimodifikasi).

\section{Penetapan kadar dengan KLT-Densitometri a. Pembuatan larutan baku Prednison}

Pembanding Prednison ditimbang $10 \mathrm{mg}$ kemudian dilarutkan dengan $10 \mathrm{~mL}$ methanol dengan konsentrasi 1000 ppm. Dari konsentrasi 1000 ppm tersebut di pipet sebanyak $2,5 \mathrm{~mL}$ dan di cukupkan hingga $5 \mathrm{~mL}$ metanol sehingga diperoleh konsentrasi 500 ppm (Wisnuwardhani et al, 2013 yang telah dimodifikasi).

\section{b. Pembuatan larutan sampel}

Sampel jamu A, B, C, D dan E hasil meserasi masing-masing ditimbang sebanyak $10 \mathrm{mg}$ kemudian dilarutkan dengan $10 \mathrm{~mL}$ etanol $96 \%$. Kemudian di pipet sebanyak $1 \mathrm{~mL}$ dan dilarutkan dengan $10 \mathrm{~mL}$ etanol 96\% (Wisnuwardhani et al, 2013 yang telah dimodifikasi).

\section{c. Penentuan kadar Prednison pada sampel}

Disiapkan lempeng KLT dengan ukuran $12 \mathrm{x}$ $10 \mathrm{~cm}$, dengan tepi atas ditandai $0,5 \mathrm{~cm}$ dan tepi bawah ditandai $1 \mathrm{~cm}$. Dari larutan baku dengan konsentrasi 500 ppm, kemudian ditotolkan dengan menggunakan mikropipet dengan variasi konsentrasi 1 $\mu \mathrm{L}, 2 \mu \mathrm{L}, 3 \mu \mathrm{L}, 4 \mu \mathrm{L}$, dan $5 \mu \mathrm{L}$. Kemudian ekstrak cair jamu A, B, C, D dan E ditotolkan dengan menggunakan mikropipet sebanyak $2 \mu \mathrm{L}$ pada lempeng KLT yang sama. Lempeng di elusi dalam chamber yang berisi kloroform : etil asetat (1:9). Noda yang terpisah diamati dengan lampu UV $254 \mathrm{~nm}$ dan diukur dengan KLT-densitometri pada panjang gelombang maksimum $254 \mathrm{~nm}$, dilakukan analisis terhadap hasil scan (Solomon, Anand \& Shukla, 2010 yang telah dimodifikasi).

\section{HASIL DAN PEMBAHASAN}

Dalam arti medis, rematik merupakan istilah yang kurang jelas dan tidak spesifik sehingga jarang dipakai dalam praktek kedokteran. Karena keluhan utamanya nyeri dan pegal-pegal. Penyakit rematik sangat mengganggu aktivitas penderita, terutama aktivitas yang memerlukan gerak tubuh (Wijayakusuma, 2006).

Rematik termasuk dalam kelompok penyakit reumatologi, yang menunjukkan suatu kondisi dengan nyeri dan kaku yang menyerang anggota gerak, yaitu sendi, otot, tulang, maupun jaringan sekitar sendi. Rematik banyak jenisnya, termasuk diantaranya asam urat (gout artritis) yang merupakan jenis rematik yang paling populer dan banyak diderita penduduk Indonesia (Wijayakusuma, 2006).

Tujuan dari penelitian ini yaitu untuk mengetahui adanya bahan kimia obat prednison yang terdapat pada jamu rematik. Pada penelitian ini dilakukan terhadap 5 sampel jamu rematik yang beredar di Makassar. Kelima sampel tersebut termasuk jenis jamu, karena masing-masing jamu terdapat gambar logo jamu pada tiap kemasan.

Prednison merupakan obat golongan kortikosteroid. Prednison ini digunakan sebagai obat rematik yang bertujuan untuk menghilangkan rasa nyeri secepat mungkin. Dosis prednison yang biasa diberikan sebagai obat rematik yaitu $20-40 \mathrm{mg}$ per hari selama 3 hari. Dosis kemudian diturunkan secara bertahap selama 1 - 2 minggu (Misnadiarly, 2007).

Prednison biasanya dicampurkan dalam jamu pegal linu, asam urat, sesak napas, dan rematik (Najib, 2009). Prednison merupakan obat golongan kortikosteroid yang digunakan untuk mengobati berbagai penyakit akut dan kronis termasuk radang sendi, asma, penyakit alergi (Vogt et al, 2007). Penggunaan obat prednison yang kurang tepat dapat menyebabkan muka bengkak, gangguan pencernaan, gangguan tulang dan otot, osteoporosis, gangguan hormon, depresi, insomnia, glaukoma, gangguan keseimbangan cairan dan elektrolit tubuh (Najib, 2009).

Untuk menarik kandungan zat-zat aktif pada jamu, dilakukan ekstraksi dengan menggunakan metode maserasi. Metode maserasi ini merupakan cara penyarian yang sederhana karena cairan penyari akan menembus dinding sel dan masuk ke dalam rongga sel yang mengandung zat aktif. Zat aktif ini akan larut dan adanya perbedaan konsentrasi antara larutan zat aktif di dalam dengan diluar sel menyebabkan larutan yang terpekat keluar hingga terjadi keseimbangan konsentrasi antara larutan di dalam dan di luar sel. Cairan penyari yang digunakan dalam proses maserasi ini adalah etanol $96 \%$. Etanol dipertimbangkan sebagai cairan penyari karena absorbsinya baik serta zat pengganggu yang larut terbatas (Pine et al, 2011). Ekstrak etanol kental yang

diperoleh dari proses maserasi yaitu untuk sampel A sebanyak 542,3 mg, sampel B sebanyak $22,2 \mathrm{mg}$, sampel C sebanyak $355,5 \mathrm{mg}$, sampel D sebanyak 115,2 mg, dan sampel E sebanyak 107,9 mg ekstrak etanol kental.

Untuk mengetahui adanya kandungan prednison dalam jamu rematik, dilakukan pengujian kualitatif dan kuantitatif. Adapun uji kualitatifnya yaitu dengan menggunakan lempeng KLT. Metode KLT digunakan karena KLT merupakan metode yang sederhana dan cepat. KLT digunakan secara luas untuk analisis obat (Gandjar \& Rohman, 2007).

Dalam metode Kromatografi Lapis Tipis (KLT), untuk mengidentifikasi prednison dalam jamu rematik dapat diamati kromatogram berdasarkan perbandingan nilai $\mathrm{Rf}$ dari masing-masing sampel dengan nilai $\mathrm{Rf}$ baku pembanding prednison. 
Sebelum diketahui nilai Rf-nya, masing-masing sampel jamu rematik dan baku pembanding ditotol pada lempeng. Setelah itu, dielusi dengan menggunakan eluen kloroform : etil asetat (1:9). kemudian, dihitung nilai Rfnya. Nilai Rf didapat dari perbandingan antara jarak titik pusat bercak dari titik awal dengan jarak garis depan dari titik awal. Warna bercak dari masing-masing sampel dan baku pembanding dapat dilihat di bawah lampu UV 254 nm. Pada lampu UV $254 \mathrm{~nm}$, prednison berwarna ungu dengan nilai Rf 0,65. Yang positif mengandung prednison, dapat dilihat dari nilai Rfnya, nilai Rf noda sampel sama dengan nilai Rf prednison.

Untuk sampel jamu A pada lampu UV $254 \mathrm{~nm}$ menunjukkan noda berwarna ungu dengan nilai $\mathrm{Rf}$ 0,65, dan pada lampu UV $366 \mathrm{~nm}$ tidak terdapatnoda. Sedangkan untuk sampel jamu B pada lampu UV 254 $\mathrm{nm}$ terdapat noda berwarna kuning dengan nilai $\mathrm{Rf}$ 0,91, dan pada lampu UV $366 \mathrm{~nm}$ terdapat noda warna kuning dengan nilai Rf 0,91. Untuk sampel jamu C pada lampu UV $254 \mathrm{~nm}$ terdapat noda berwarna kuning dengan nilai $\mathrm{Rf} 0,95$, dan pada lampu UV $366 \mathrm{~nm}$ juga terdapat noda warna kuning dengan nilai Rf 0,95. Sedangkan untuk sampel jamu D pada lampu UV $254 \mathrm{~nm}$ terdapat noda berwarna kuning dengan nilai $\mathrm{Rf} 0,91$ dan 0,95 begitupun juga pada lampu UV $366 \mathrm{~nm}$ terdapat noda berwarna kuning dengan nilai Rf 0,91 dan 0,95. Dan untuk sampel jamu E pada lampu UV $254 \mathrm{~nm}$ terdapat noda berwarna kuning dengan nilai Rf 0,91 begitupun pada lampu UV $366 \mathrm{~nm}$ terdapat noda berwarna kuning dengan nilai Rf 0,91. Berdasarkan hal tersebut, sampel jamu yang positif mengandung prednison adalah sampel jamu A karena memiliki nilai $\mathrm{Rf}$ dan warna noda yang sama dengan prednison yaitu dengan nilai Rf 0,65 dan noda berwarna ungu.

Tabel 1. Hasil identifikasi Prednison dengan menggunakan metode Kromatografi Lapis Tipis (KLT)

\begin{tabular}{|c|c|c|c|c|c|c|c|c|c|c|}
\hline \multirow[b]{2}{*}{ No } & \multirow[b]{2}{*}{ Jamu } & \multicolumn{4}{|c|}{ Nilai Rf Sampel } & \multicolumn{4}{|c|}{ Nilai Rf Pembanding } & \multirow[b]{2}{*}{ Prednison } \\
\hline & & $254 \mathrm{~nm}$ & $\begin{array}{l}\text { Warna } \\
\text { Noda }\end{array}$ & $366 \mathrm{~nm}$ & $\begin{array}{l}\text { Warna } \\
\text { Noda }\end{array}$ & $254 \mathrm{~nm}$ & $\begin{array}{l}\text { Warna } \\
\text { Noda }\end{array}$ & $366 \mathrm{~nm}$ & $\begin{array}{l}\text { Warna } \\
\text { Noda }\end{array}$ & \\
\hline 1 & Jamu A & 0,65 & Ungu & - & - & 0,65 & Ungu & - & - & + \\
\hline 2 & Jamu B & 0,91 & Kuning & 0,91 & Kuning & 0,65 & Ungu & - & - & - \\
\hline 3 & Jamu C & 0,95 & Kuning & 0,95 & Kuning & 0,65 & Ungu & - & - & - \\
\hline \multirow{2}{*}{4} & \multirow{2}{*}{ Jamu D } & 0,91 & Kuning & 0,91 & Kuning & 0,65 & Ungu & - & - & - \\
\hline & & 0,95 & Kuning & 0,95 & Kuning & & & & & - \\
\hline 5 & Jamu E & 0,91 & Kuning & 0,91 & Kuning & 0,65 & Ungu & - & - & - \\
\hline $\begin{array}{l}\text { hengg } \\
\text { pis } \\
\text { ang o } \\
\text { enyav } \\
\text { apat c } \\
\text { uatu } \\
\text { eperti } \\
\text { enger } \\
\text { kstrak } \\
\text { enger } \\
\text { aja ul } \\
\text { nalis }\end{array}$ & $\begin{array}{l}\text { Adapun } \\
\text { nakan alat } \\
\text { LTT)-Den } \\
\text { pat meng. } \\
\text { dalam } \\
\text { gunakan p } \\
\text { Instrume } \\
\text { erangkat } \\
\text { halnya sp } \\
\text { annya ha } \\
\text { dan vo } \\
\text { aannya ha } \\
\text { Iran lemp } \\
\text { Prednis }\end{array}$ & $\begin{array}{l}\text { uji kua } \\
\text { KLT-Den } \\
\text { itometri r } \\
\text { nalisis sec } \\
\text { ampuran } \\
\text { ada kadar } 1 \\
\text { KLT-Der } \\
\text { optik, sur } \\
\text { ktrofotom } \\
\text { us diperha } \\
\text { ume yan } \\
\text { npir sama } \\
\text { ng yang d }\end{array}$ & $\begin{array}{l}\text { titatifnya } \\
\text { tometri. K } \\
\text { erupakan } \\
\text { ra kualitat } \\
\text { engan wa } \\
\text { cil (Sugij } \\
\text { itometri d } \\
\text { ber cahay } \\
\text { ter (Hayu } \\
\text { kan cara } \\
\text { ditotolk } \\
\text { engan me } \\
\text { gunakan y } \\
\text { KIT }\end{array}$ & $\begin{array}{l}\text { yaitu } \\
\text { omatogra } \\
\text { metode } \\
\text { f dan kua } \\
\text { tu singki } \\
\text { nto et al, } \\
\text { lengkapi } \\
\text {, dan d } \\
\text { 2007). } \\
\text { enotolan } \\
\text { h harus } \\
\text { de KLT. } \\
\text { itu } 12 \mathrm{x} \\
\text { sitometri }\end{array}$ & $\begin{array}{l}\text { engan } \\
\text { lapis } \\
\text { alisis } \\
\text { titatif } \\
\text { dan } \\
\text { 10). } \\
\text { engan } \\
\text { tector } \\
\text { alam } \\
\text { ampel } \\
\text { sama. } \\
\text { Janya } \\
\text { cm. }\end{array}$ & $\begin{array}{l}\text { panjang ge } \\
\text { gelombang } \\
\text { pembanding } \\
\text { Dan nilai } \\
\text { Sedangkan } \\
\text { Da } \\
\text { mengandun } \\
\text { sampel jam } \\
\text { Adapun kad } \\
\text { dengan pers } \\
\text { Tabel } 2 \text { : } \\
\text { rematik seca }\end{array}$ & $\begin{array}{l}\text { lombang } \\
\text { maksimu } \\
\text { predniso } \\
\text { Rf pem } \\
\text { nilai Rf pa } \\
\text { ri hasil m } \\
\text { g Prednis } \\
\text { a A dan n } \\
\text { lar predni } \\
\text { entase 4,7 } \\
\text { Hasil ide } \\
\text { ra KLT-I }\end{array}$ & $\begin{array}{l}\text { maksimun } \\
254 \mathrm{nn} \\
1 \mu \mathrm{L}, 2 \mu \\
\text { anding pr } \\
\text { da sampel j } \\
\text { nunjukkan } \\
\text { n. Hal ini } \\
\text { ai Rf baku } \\
\text { one pada j } \\
4 \% \text {. } \\
\text { tifikasi Pr } \\
\text { ensitometri }\end{array}$ & $\begin{array}{l}254 \text { nm. } \\
\text { diperoleh } \\
3 \mu \mathrm{L} \text {, dan } \\
\text { dnison } 5 \\
\text { mu A yaitu } \\
\text { ahwa sampe } \\
\text { didasarkan } \\
\text { membanding } \\
\text { mu A yaitu } \\
\text { dnison pada }\end{array}$ & $\begin{array}{l}\text { Pada panja } \\
\text { nilai Rf unt } \\
4 \mu \mathrm{L} \text { yaitu } 0, \\
\mu \mathrm{L} \text { yaitu } 0,6 \\
0,63 \text {. } \\
\text { el jamu A posi } \\
\text { karena nilai } \\
\text { prednison san } \\
475,421 \mu \mathrm{g} / \mathrm{n} \\
\text { a beberapa jar }\end{array}$ \\
\hline \multirow{2}{*}{\multicolumn{6}{|c|}{$\begin{array}{l}\text { Pengerjaannya hampir sama dengan metode KLT. Hanya } \\
\text { saja ukuran lempeng yang digunakan yaitu } 12 \times 10 \mathrm{~cm} \text {. } \\
\text { Analisis Prednison secara KLT Densitometri pada }\end{array}$}} & Sampel & $\begin{array}{l}\text { Nilai } \\
\text { Rf }\end{array}$ & $\begin{array}{l}\text { Luas } \\
\text { Area }\end{array}$ & $\begin{array}{l}\text { Kadar } \\
\text { Prednison } \\
(\mu \mathrm{g} / \mathrm{mL})\end{array}$ & $\begin{array}{c}\text { Kadar } \\
\text { Prednison } \\
(\%)\end{array}$ \\
\hline & & & & & & Jamu A & 0,63 & 7535,5 & 475,421 & 4,7542 \\
\hline
\end{tabular}




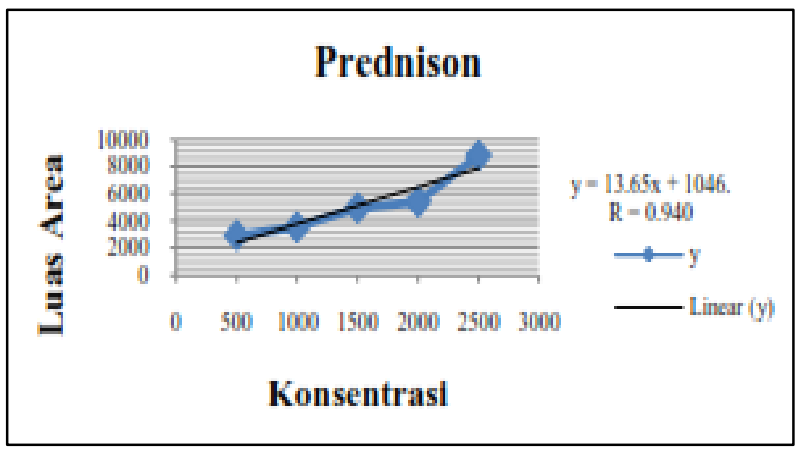

Gambar 1. Grafik kurva Predniason secara KLTDensitometri

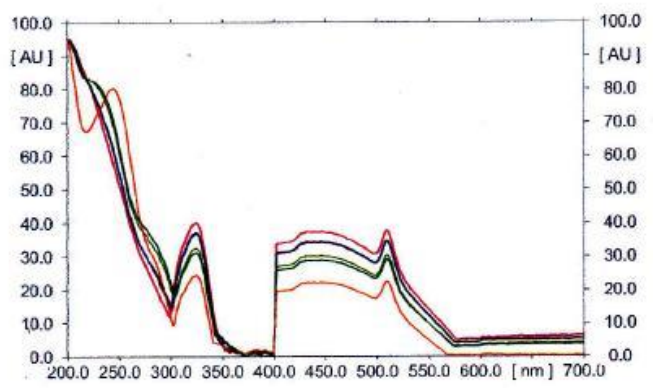

Gambar 2. Panjang gelombang Prednison pada jamu rematik secara KLT-Densitometri

Keterangan : Prednison $1 \mu \mathrm{L}(202 \mathrm{~nm})$ Prednison $2 \mu \mathrm{L}(200 \mathrm{~nm})$

Prednison $3 \mu \mathrm{L}(200 \mathrm{~nm})$ Prednison $4 \mu \mathrm{L}(200 \mathrm{~nm})$ Prednison $5 \mu \mathrm{L}(200 \mathrm{~nm})$

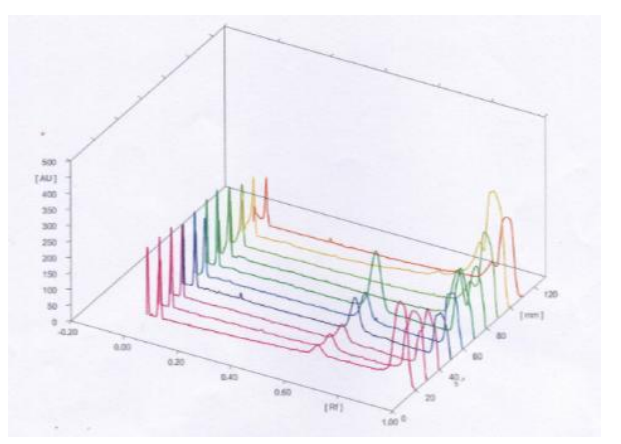

Gambar 3. Profil hasil KLT-Densitometri

\section{KESIMPULAN}

Berdasarkan hasil penelitian yang telah dilakukan maka dapat disimpulkan bahwa terdapat satu jenis jamu yang positif mengandung prednison dari lima jenis jamu yang diidentifikasi yaitu jamu A. kadar prednison yang terkandung dalam jamu $\mathrm{A}$ yaitu $475,421 \mu \mathrm{g} / \mathrm{mL}$ dengan persentase $4,754 \%$.

\section{DAFTAR PUSTAKA}

Cosman, F. 2011. Osteoporosis. Yogyakarta: Panduan Kesehatan Wanita.

Firdaus, M. I., \& Utami, P. I. 2009. Analisis Kualitatif Parasetamol pada Sediaan Jamu Serbuk Pegal Linu yang Beredar di Purwokerto. Vol: 06. No: 02. ISSN: 1693-3591

Gandjar, I.G., \& Rohman, A. 2007. Kimia Farmasi Analisis. Yogyakarta: Universitas Gadjah Mada.

Hayun., Leswara, N. D., \& Masrijal, D. P. 2007. Penetapan Kadar Triprolidina Hidroklorida dan Pseudoefedrina Hidroklorida dalam Sediaan Sirup Obat Influenza secara Kromatografi Lapis Tipis Densitometri. Majalah Ilmu Kefarmasian. Vol. IV, No. 2 : $59 \quad-72 . \quad$ (Online) (http://journal.ui.ac.id/index.php/mik/article/ view/1188). Diakses tanggal 18 September 2013).

Misnadiarly, 2007. Rematik: Asam UratHiperurisemia, Arthritis Gout. Jakarta: Pustaka Obor Populer

Najib, A. 2009. Waspadai Bahan Kimia yang Dioplos dalam Jamu. (Online) (http://nadjeeb.wordpress.com/2009/10/15/ waspadai-bahan-kimia-yang-dioplos-dalamjamu/).Diakses tanggal 16 September 2013.

Pine, A.T., Alam, G., Attamin, F. 2011. Standarisasi mutu dan ekstrak daun Gedi (Abelmoschus manihot L) Medik) dan uji efek antioksidan dengan metode DPPH. Makassar : Universitas Hasanuddin.

Solomon, W.D.S., Anand, P.R.V., \& Shukla, R. 2010. Aplication of TLC-Densitometri Method for Simultaneous Estimation of Tramadol $\mathrm{HCl}$ and Paracetamol in Pharmaceutical Dosage Forms. (Online) (www.sphinxsai.com). Vol : 2. No : 2 . ISSN : 0974 - 4290 Diakses tanggal 1 Maret 2014.

Sugijanto, Prihatin \& Sugijanto, N. E. 2010. Analisis Pestisida Karbaril dengan metode KLT-Densitometri dalam Matriks Kedelai dan Validasi Metodenya. Berk Penel Hayati. 15 : 165-169. (Online) (http://www.berkalahayati.org/index.php/bp 
h/article/view/). Diakses tanggal 18 September 2013.

Tandra, H. 2009. Segala Sesuatu yang Harus Anda Ketahui tentang Osteoporosis. Jakarta : Penerbit PT Gramedia Pustaka Utama Anggota IKAPI.

Vogt, et al. 2007. Biowaiver Monographs for Immediate Release Solid Oral Dosage Forms: Prednison. Journal of Pharmaceutical Sciences. Vol. 96, NO 1 : 27-37. (Online) (http://www.fip.org/files/ fip/BPS/ BCS/Monographs/Prednisone.pdf Diakses tanggal 18 September 2013.

Wijayakusuma, H.M. 2006. Atasi Asam Urat dan Rematik Ala Hembing. Depok : Penerbit Puspa Swara, Anggota Ikapi.

Wisnuwardhani, H. A., Fidrianny, I., \& Ibrahim, S. 2013. Method Development for Simultaneous Analysis of Steroid and Non Steroid Antiinflamatory Substances in Jamu Pegal Linu Using TLCSpectrophotodensitometry. Vol. 5, Issue 4. (Online) (http://www.ijppsjournal.com/ Vol5Issue4/7897.pdf). Diakses tanggal 1 Maret 2014.

Yuliarti, N. 2010. Sehat, Cantik, Bugar, dengan Herbal dan Obat Tradisional. Penerbit ANDI.

Ansel, H. Pengantar Bentuk Sediaan Farmasi Edisi IV. Jakarta: Universitas Indonesia Press. 1989

Edhisambada. 2011. Metode Uji Aktivitas Antioksidan Radikal 1,1-Difenil-2-Pikrilhidrazil $(D P P H)$. http://edhisambada.wordpress.com. (10 september 2013).

Miksusanti et, al. Aktivitas Antioksidan dan Sifat Kestabilan Warna Campuran Ekstrak Etil Asetat Kulit Buah Manggis (Garcinia mangostana L.) dan Кауи Secang (Caesalpinia sappan L.). Sumatera Selatan: Jurusan Kimia Universitas Sriwijaya, 2012. Vol 15 Nomor 2 C, p 1-2

Moon JK, Shibamoto T. Antioxidant assays for plant and food components. Journal of Agricultural and Food Chemistry. 2009. Nomor 57, p 1655-1666.
Jusuf, Nelva Karmila. Pengaruh Ekstrak Bunga Brokoli (Brassica oleraceae L. var Italica Plenk) Terhadap Penghambatan Penuaan Kulit Dini (Photoaging): Kajian pada Ekspresi Matriks Metalloproteinase-1 dan Prokolagen Tipe 1 Secara in vitro pada Fibroblas Manusia. Medan: Fakultas Kedokteran Sumatera Utara, 2012. p 6

Widyastuti, N. Pengukuran Aktivitas Antioksidan dengan Metode CUPRAC, DPPH dan FRAP serta Korelasinya dengan Fenol dan Flavonoid pada Enam Tanaman. Departemen Kimia Fakultas Matematika dan Ilmu Pengetahuan Alam Institut Pertanian Bogor. 2010

Winarsi, Hery. Antioksidan Alami dan Radikal Bebas. Yogyakarta: Penerbit Kanisius, 2007. p 15

Yuliani, Fitri. Isolasi Senyawa Lutein Dari Ekstrak Bunga Brokoli Sebagai Antioksidan. Bogor: Fakultas MIPA Institut Pertanian Bogor, 2012. p 9 